\title{
PRAGMATIC USE OF ANCIENT GREEK PRONOUNS IN TWO COMMUNICATIVE FRAMEWORKS
}

\author{
Chiara Meluzzi
}

\begin{abstract}
This paper deals with the use of personal pronouns (PPs) in Ancient Greek in two Aristophanes' comedies (i.e. Lysistrata and Ecclesiazusae). The main purpose of this study is to show that Ancient Greek PPs often have a pragmatic function, in particular linked to the speaker's communicative goals.

The analysis highlights the presence of a gender-related distribution and a context-dependent use of personal pronouns. In particular, male characters prefer 1st person singular pronouns, whereas female characters use more 1st person plural pronouns with an inclusive value. Moreover, in two communicative frameworks it is possible to notice how PPs are used for their value of membership categorization. In this respect PPs can be considered possible markers of autonomía or afiliación (see Bravo 1999). Some peculiar instances of referential ambiguities concern in particular the use of 1st and 2nd person plural pronouns in both comedies.

The analysis shows that use of Ancient Greek PPs varies according to gender and context. Moreover, it is clear that in both comedies this variation should be explained mainly as a pragmatic strategy of membership categorization, thus showing instances of non-prototypical uses of PPs similar to other languages (e.g. Spanish, English, Modern Greek).
\end{abstract}

Keywords: Personal pronouns; 1st person plural pronouns; Communicative framework; Membership categorization; Ancient Greek.

\section{Introduction}

Personal pronouns (henceforth, PPs) are usually analysed for their deictic or anaphoric function. However, in the last few decades pragmatic studies have shown how PPs do more than that, and may cover a broader range of functions, which are commonly described as non-prototypical. Maybe the best known examples of non-deictic use of PPs are the majestic plural and the so-called "business we" (Brown \& Levinson 1987: 202). Recently, scholars have addressed the issue of non-prototypical use of PPs in naturally occurring data in different languages (e.g., Mühlhäuser \& Harré 1990). On the other hand, scholars working on ancient languages (e.g. Latin, Ancient Greek) have only recently started to apply pragmatic theories to their studies ${ }^{1}$, mostly because of the

1 Important exceptions are represented by McClure (1999), Bain (1984), Adams (1984), Sommerstein (1995), Willi (2003), and Bonifazi (2004), among others, who address in particular the 
developing of Historical Sociolinguistics and Historical Pragmatics. However, to our knowledge Ancient Greek PPs have not yet been addressed from a pragmatic perspective, even if some scholars have tried to distance themselves from the classical deictic interpretation (e.g. Dickey 1996).

In this paper, PPs occurring in two Ancient Greek comedies will be considered by emphasizing how PPs could be used non-prototypically, since it is possible to detect «some kind of additional pragmatic meaning (or connotation) associated with [their] use», as pointed out in Helmbrecht (2015: 178). The author also emphasizes two further properties of non-prototypical use of PPs: (a) the modification of the prototypical set and a shift in the pronominal category, and (b) the restriction of the non-prototypical use to certain contexts. The first property does not appear in our data, which represent only a small part of the production of a single author. However, Ancient Greek PPs appear to vary according to the pragmatic and the discourse context, thus showing two of the three properties of non-prototypical use indicated by Helmbrecht (2015).

Theoretically speaking, the analysis is based on Tannen's (1990) notion of communicative style and on Bravo's (1999) concepts of autonomía and afiliación (section 3). It is worth to remark that the analysis follows a qualitative approach: Even when frequencies and graphs are presented, their use must be intended only as a description of the phenomenon under analysis, without any quantitative claim attached to them. It should also be considered that few instances are sometimes available since the corpus is limited ${ }^{2}$. The results (section 4) illustrate how the use of Ancient Greek PPs is both gender- and context-related. Moreover, it will be claimed that 1st person plural and 1st person singular pronouns are used as markers for membership categorization $^{3}$, in order to either enhance group unity or to mark the speaker distance from his/her addressees (see Brown \& Levinson 1987: 198-200). Some instances also show a referential ambiguity, which is distinctive in interactions among characters, and it is also reflected in the English translations of the comedies (e.g., Sommerstein 1990). The results emerging from the analysis of Ancient Greek PPs are in line with considerations that have already been advanced for other languages (e.g., Spanish, English): In particular, 1st person plural pronouns are confirmed as important features in the pragmatic process of identity negotiation through interaction (section 5).

\section{The data: Texts and problems}

This study is based on two comedies written by the playwright Aristophanes, whose production corresponds to the so-called classic period of Athenian history (V-IV c. BC). According to ancient sources, Aristophanes wrote up to 45 comedies, but only 11 have been preserved in their entirety through the centuries. Female characters can be found in title roles in three comedies": Lysistrata and Thesmophoriazusae ("Women to the

difference between male and female speech. Personal pronouns in Greek tragedy are also the focus of Bruno's (forthcoming) analysis.

${ }^{2}$ Stewart (2003: 198) points out the «difficulties inherent in trying to apply a quantitative approach systematically».

${ }^{3}$ See Sacks, Schegloff \& Jefferson (1974), and Jefferson (2007).

${ }^{4}$ It is useful to remember that in Ancient Greek theatrical tradition female parts were also portrayed by male actors. 
Feast"), both represented in 411 BC at two different dramatic contests, and Ecclesiazusae ("Women to the Assembly") which was first represented represented in 392 BC $^{5}$. In this study we consider only Lysistrata and Ecclesiazusae (henceforth, Lys. and $E c c l$.) because they show many resemblances ${ }^{7}$.

Lysistrata was first represented during the Peloponnesian War between Athens and Sparta (431-404 BC), and, as a consequence, the central theme of this comedy is peace. The protagonist, the Athenian woman Lysistrata, organises a female sexual strike in order to force Athenian and Spartan men to make peace; she also occupies the Acropolis, where the Athenian treasure is preserved. Ecclesiazusae was represented after the end of the Peloponnesian War and Athens's defeat by Sparta. The central theme is the good government of the town: Since men have proven themselves incapable of preserving Athens' prosperity, the female protagonist Praxagora and other Athenian women disguise themselves as men, speak at the Athenian Assembly and vote for assigning the political power to women.

The main similarities between the two comedies are (1) the presence of a strong female protagonist, i.e. Lysistrata and Praxagora, along with many other female supporting characters, and (2) the role assigned to men as the protagonists' opponents. In both comedies dialogues may involve only female characters, male and female characters, and also only male characters. The latter case is to be found in most other comedies written by Aristophanes, where female characters are rare, and generally only occur in the role of servants who speak very few lines. Therefore, the only examples of female dialogues in Greek classic comedy are those found in the three mentioned comedies and, in particular, in Lys. and Eccl. In this respect, it is easy to note how gender and gender opposition are important issues in both comedies.

However, these comedies present two important differences. Firstly, in Eccl. women must resort to disguising themselves as men, whereas no such trick is necessary in Lys. Secondly, a direct opposition between men and women is portrayed only in Lys., whereas in Eccl. the female protagonist is the only woman on stage to argue against Athen's men. These differences are important for the analysis as they involve a different use of PPs (see 4.3), but they do not erase the similarities shared by the two comedies, thus still allowing for a comparison of the pragmatic use of PPs in these two texts.

Ancient texts present many philological problems, particularly related to characters' identification and philological variants of the texts. As a matter of fact, ancient manuscripts did not always provide the characters' names, leaving the attribution of some lines to scholars, who based their assumptions on philological, textual, and contextual considerations. As a consequence, speakers' identity is

${ }^{5}$ For the problems of the precise dating of these texts, see MacDowell (1995) and Sommerstein (1977). The dating refers to the first representations of the comedies. In the classical period, comedies and tragedies were usually performed only once at one of the two big Athenian festivals; however, scholars think that the most popular drama would probably be performed again in small theatres in the colonies.

${ }^{6}$ From now on we abbreviate the name of the comedies according to the conventions of Greek philology, so that Lys. stands for Lysistrata and Eccl. for Ecclesiazusae.

${ }^{7}$ As a matter of fact, in Thesmophoriazusae many lines are spoken by male characters disguised as women. Both Sommerstein (1995) and Willi (2003) consider those lines as female speech, but it is maybe better to consider Thesmophoriazusae as an exceptional case (see Meluzzi 2010 and 2012). The same can be said for Eccl., in which female characters are disguised as male: those lines are considered as "male speech" by previous scholars, whereas here they will be considered as particular instances, thus differentiating these lines from both prototypical male and female speeches. 
sometimes very problematic, and different editions of the same text may present different attributions of specific lines ${ }^{8}$. The presence of textual variants is another phenomenon related to the history of the transmission of these texts. This issue is particularly problematic for small linguistic elements like PPs, which could easily be omitted, misspelled or substituted during the manual copy of the texts throughout the centuries. This is a well-known problem for linguists working with ancient written materials, and it has been recently addressed by Historical Sociolinguistics (see Hernández-Campoy \& Conde-Silvestre 2012). In the case at present, a possible, although not a perfect solution is a preliminary evaluation of the modern critical editions, and the selection of one of them as reference. This study is therefore based on Wilson's (2007) edition of Aristophanes' comedies for the Greek original versions, ${ }^{9}$ while the English translations for Lys. and Eccl. come from Sommerstein (1990) and (1998).

\section{Theory and method}

Ancient Greek (pro)nouns have four cases (i.e., nominative, genitive, accusative, and vocative). Since Greek is a pro-drop language, PPs in the nominative case may be omitted because the person is already marked on the verb ${ }^{10}$. For the present study, only the explicit instances of PPs have being examined, firstly without differentiating among cases and, then, by concentrating mainly on subject PPs for the specific discourse analysis concerning the two protagonists of the comedies (see 4.2) ${ }^{11}$. A manual count of the tokens was carried out, with special attention to 1 st person plural pronouns (gr. hèmeîs ${ }^{12}$ ): Since Ancient Greek does not distinguish between inclusive and exclusive

${ }^{8}$ For instance, in Ecclesiazusae the two men arguing against Praxagora at lines 520-727 have been variously identified as her husband Blepyrus and his friend Chremes, or, alternatively, as the same Blepyrus and an unnamed Neighbour.

${ }^{9}$ Many other critical editions of these texts are available, as well as the online edition of the Thesaurus Linguae Graecae. Henderson (1987) is also an important edition of Lys., as is Ussher (2007) for Eccl. For a discussion of the philological tradition and problems of these two comedies, see Meluzzi (2010: 8-12 and 20-24). Wilson (2007) is a philological edition of Aristophanes, thus containing only the Greek text.

${ }^{10}$ In this respect, Spanish is a well-studied pro-drop language: for instance, Davidson (1996) emphasizes the "pragmatic weight" of the PPs of first and second person singular in spoken Madrid Spanish (see also Stewart 2003).

${ }^{11}$ Obviously, the decision to consider only explicit instances of PPs affects both the corpus and the research design. As it is well known, in pro-drop languages (e.g., Spanish) explicit mentioning of the subject PP could carry certain pragmatic effects. However, this has never been analysed for Ancient Greek, in which omission or explicit mentioning of a PP may also be connected to metrical considerations related to the poetic structures of some texts (e.g., comedies, tragedies, and so on). Moreover, Ancient Greek pronominal system distinguished between stressed and unstressed PPs (e.g., emô̂ / mou "mine") for first and second person singular PPs, which could also present the enclitic particle -ge at their end (e.g., súge, meaning "you" but possibly also "even you"). Again, this aspect has never been addressed by pragmatic research so far, and it would certainly represent an interesting aspect in the analysis of pragmatic use of PPs. In this sense, the present research aims at representing a first insight in the pragmatic use of PPs in Ancient Greek comedy.

${ }^{12}$ Greek pronouns are reported between parentheses in the nominative case, with the exceptions of explicit textual quotes (see 4.2). 
values of this pronoun at a lexical level ${ }^{13}$, a case-by-case evaluation was necessary based the on speaker's intention to include/exclude the addressee. For instance, in Lys. 120-1, the protagonist addresses the other women on stage with a 1st person plural pronoun with a clear inclusive value, whereas this pronoun has an exclusive value ${ }^{14}$ when she speaks to the Magistrate (Lys. 493). It appears clear that in these cases first person plural pronouns could be used in a non-prototypical way, for instance as markers of membership categorization $(\$ 4.2 .2)$.

This first analysis gives a general survey of PPs use in both texts and by different characters (see 4.1). Therefore, it is clear that the decision of which value is carried on by the various 1st person plural pronouns has been part of a preliminary pragmatic analysis, which considered each instance and the context of the whole utterance (see Meluzzi 2010: 25-66).

PPs have then been used to identify the communicative style preferred by each character. The analysis is theoretically based on the definition of communicative styles provided in Tannen (1990: 77), who distinguishes between

(a) report-speaking communicative style, characterized «by exhibiting knowledge and skill, and by holding the centre of the stage through verbal performance»;

(b) rapport-speaking communicative style, where «emphasis is placed on displaying similarities and matching experiences».

Although Tannen (1990) does not explicitly refer to PPs to identify such styles, in a later work she explicitly notes how «even so small a linguistic strategy as the choice of pronouns can have the effect of making one's contributions more or less salient» (Tannen 1994: 137). As it has been previously pointed out in Brown \& Levinson's (1987) politeness theory, PPs are used to establish and negotiate relationships between speaker and hearer through the conversation (see also Helmbrecht 2003 for a large cross-linguistic analysis of PPs and politeness). For instance, plural PPs could be used in positive politeness strategies aiming to include both the speaker and the hearer in the activity (strategy 12, Brown \& Levinson 1987: 127). PPs could also be in-group identity markers (positive politeness strategy 4, Brown \& Levinson 1987: 107). As for negative politeness, PPs could be used to impersonalize both the speaker and the hearer (strategy 7, Brown \& Levinson 1987: 190-203), for instance by replacing first and second person pronouns with their plural forms, which may result in referential ambiguity (\$4.2.2).

In this contribution, pronouns of 1st person singular (gr. eg⿳亠े⿵冂), 2nd person plural (gr. hymeîs), and 1st person plural with an exclusive value (gr. hèmeîs) have been judged as markers for report-speaking communicative styles. This assumption has been made on the theoretical consideration that these pronouns isolate the speaker and oppose him/her to his/her audience. Indeed, Brown \& Levinson (1987: 198) point out that 2nd person plural pronouns are used to distance the hearer, since "'you' (plural) provides a conventional 'out' of the hearer. That is, since it does not literally single out the

\footnotetext{
${ }^{13}$ For the inclusive and exclusive value of 1 st person plural pronouns, see the good schema in De Cock (2011). Siewierska (2004) reports many instances of languages that lexically differentiate between inclusive and exclusive 1 st person plural pronouns.

${ }^{14}$ In fact, in the following line (v. 494) the Magistrate replicates with a second person plural pronoun (gr. hymeîs); the pragmatic value of these pronouns in this textual portion will be fully addressed in section 4.2.
} 
addressee, it is as if the speaker were giving $\mathrm{H}$ [i.e., the hearer] the option to interpret it as applying to him rather than, say, to his companions» ${ }^{15}$. Thus, 1 st person singular, 2nd person plural, and 1st person exclusive plural pronouns allow the speaker to metaphorically hold the centre of the stage, similar to the assumptions made for Tannen's (1990) definition of report-speaking communicative style, and by Hirschmann's (1994) findings about the use of 1st person singular pronouns in one-tomany discussions.

On the other hand, pronouns of 2nd person singular (gr. sý), and 1st person plural with an inclusive value (gr. hèmeîs) are judged as markers for rapport-speaking communicative style. In fact, these pronouns implicate that the addressee is directly involved in the speaker's sentence. Concerning $2^{\text {nd }}$ person singular pronoun, Stewart (2003: 202) has pointed out how these PPS «are aiming at establishing solidarity with their hearer». The implicit (i.e., contextual) inclusive reference of $1^{\text {st }}$ person plural forms are considered as markers of positive politeness «with the implicature that the needs and desires of $\mathrm{S}$ and $\mathrm{H}$ are compatible and that both are solidary» (Stewart 2001: 161). This pragmatic difference between pronouns could also be encoded in Tannen's (1990) distinction between a report and a rapport-speaking communicative styles.

After having provided an analysis of PPs use in both texts, the second part of the analysis will follow a more discursive approach, and also address the issue of PPs' referential ambiguity. The general assumption is that in some contexts a speaker may pursue two opposite pragmatic aims, that is (1) distinguish him/herself from a group, and (2) identifying him/herself as part of that group. These aims will be referred to with Bravo's (1999: 161) notions of autonomía (autonomy) and afiliación (affiliation) respectively.

The emergence of these pragmatic aims is furthermore evident in two communicative frameworks, which have been identified on the basis of the "SPEAKING model" in Hymes (1974) $)^{16}$, with a particular emphasis on participants, ends, acts and norms of interpretation. It is important to stress that these frameworks have been preliminary identified based only on contextual considerations, and not on the presence or absence of certain PPs (which would have obviously led to a circulatory analysis). In fact, the first framework is characterized by the opposition of two or more participants, and many speech acts of imposing and persuading in a mostly direct way, often with many FTAs without a redressive action (see Brown \& Levinson 1987: 60). This framework has been labelled "fighting", and it has been found in five instances (Lys. 430-613, Lys. 1112-1188, Eccl. 520-724, Eccl. 746-876, and Eccl. 884-937). The second communicative framework is characterized by speakers' desire to enhance group solidarity, with a balanced distribution of turns (Sacks, Schegloff \& Jefferson 1974), and the lack of direct FTAs in order to avoid an open contrast among participants and to achieve a common agreement on the topic of the conversation. This framework has been labelled "chatting", and three instances have been detected in the two comedies (Lys. 1-

${ }^{15}$ It appears also evident from this quotation how plural pronouns may be directly related to referential ambiguity, as it will be later shown with respect to the Ancient Greek data (§ 4).

16 Namely, each context could be described in terms of setting, participants, ends of the interaction, acts, key, instrumentalities, norms and genre. These elements play a different role, even if the "key" is, by definition, the fundamental one to interpret the context of interaction; see Hymes (1974). 
253, Eccl. 1-284, and Eccl. 372-477) ${ }^{17}$. The analysis will show how these communicative frameworks show a non-prototypical use of PPs, which should be interpreted not as mere deictic but as carrying different pragmatic meanings according to the context (Helmbrecht 2015).

\section{Results}

According to the methods and theoretical models previously illustrated, the analysis is divided in a first general part (\$4.1) showing the overall distribution of PPs among the different characters of the two comedies, and a second part (\$4.2) concerning the use of PPs in discourse. In both cases, a specific focus is provided on the two female protagonists (i.e., Lysistrata and Praxagora). A final summary ( $\$ 4.3$ ) will relate the main results to the theoretical framework previously illustrated.

\subsection{Distribution of PPs in the comedies}

A first general survey of PPs use is summed up in table 1 (for Lys.) and table 2 (for $E c c l$.). Characters' names are listed on the left in order of appearance on stage, distinguishing among female and male characters. The tables also present both tokens and percentage of PPs use. As a matter of fact, tokens may allow only broad considerations, due to the different size of the two comedies, in terms of number of lines and of words. However, a normalization of these occurrences (e.g., with respect to a fixed number of words) faces many difficulties related to the philological problems of these texts (see section 2), and to the very few occurrences found for some characters (see also Meluzzi 2012). In order to compare the two comedies, simple percentages of PPs frequency have been calculated for each character depending on the total amount of PPs contained in that character's lines.

More PPs could be found in Lys. than in Eccl. (413 vs. 354 tokens). This is particularly interesting since Eccl. has more characters than Lys., even if many of them utter very few lines. Thus, there are characters in both comedies who use less than 10 PPs each, with the extreme case of the Female Herald in Eccl. with only 1 PP attested. Therefore, it is necessary to consider a basic division between main and minor characters based on the total amount of lines (and PPs) uttered ${ }^{18}$. Obviously, in both comedies the two protagonists produce the highest number of PPs (123 Lysistrata, 62 Praxagora), and both are characterized by a high use of 1 st person singular pronouns (36 Lysistrata, 25 Praxagora). Lysistrata, however, utters more 2nd person plural pronouns than Praxagora, and the same can be said concerning 1st person plural pronouns, with both an inclusive and an exclusive value.

${ }^{17}$ Not every line of the two texts belong to the already identified fighting and chatting framework, since they do not show elements in common with neither of them. Further research may identify other communicative frameworks, thus offering a complete classification of the comedy according to Hymes's (1974) model.

${ }^{18}$ Also note that those minor characters are always the most controversial ones, especially in terms of speakers' identification on stage (see Olson 1992). 


\begin{tabular}{|c|c|c|c|c|c|c|c|}
\hline & & I & You sg. & We incl. & We excl. & You pl. & Total \\
\hline \multirow[t]{7}{*}{$\begin{array}{l}\text { Female } \\
\text { characters }\end{array}$} & Lysistrata & $\begin{array}{l}36 \\
(29,3 \%)\end{array}$ & $\begin{array}{l}25 \\
(20,3 \%)\end{array}$ & $\begin{array}{l}13 \\
(10,6 \%)\end{array}$ & $\begin{array}{l}19 \\
(15,4 \%)\end{array}$ & \begin{tabular}{|l|}
30 \\
$(24,4 \%)$
\end{tabular} & $\begin{array}{l}123 \\
(100 \%)\end{array}$ \\
\hline & Kalonike & $\begin{array}{l}6 \\
(46,2 \%)\end{array}$ & $3(23,1 \%)$ & $4(30,8 \%)$ & - & - & $13(100 \%)$ \\
\hline & Myrrhine & $\begin{array}{l}23 \\
(52,3 \%)\end{array}$ & $\begin{array}{l}14 \\
(31,8 \%)\end{array}$ & $5(11,4 \%)$ & $\begin{array}{l}1 \\
(2,3 \%)\end{array}$ & $\begin{array}{l}1 \\
(2,3 \%)\end{array}$ & $44(100 \%)$ \\
\hline & Lampito & $\begin{array}{l}5 \\
(83,3 \%)\end{array}$ & - & - & $1(16,7 \%)$ & - & $\begin{array}{l}6 \\
(100 \%)\end{array}$ \\
\hline & Female Chorus & $\begin{array}{l}30 \\
(47,6 \%)\end{array}$ & $\begin{array}{l}19 \\
(30,2 \%)\end{array}$ & \begin{tabular}{|l|}
3 \\
$(4,8 \%)$
\end{tabular} & $\begin{array}{l}3 \\
(4,8 \%)\end{array}$ & \begin{tabular}{|l|}
8 \\
$(12,7 \%)$
\end{tabular} & $\begin{array}{l}63 \\
(100 \%)\end{array}$ \\
\hline & Other Women & $\begin{array}{l}11 \\
(78,6 \%)\end{array}$ & $\begin{array}{l}1 \\
(7,1 \%)\end{array}$ & $\begin{array}{l}1 \\
(7,1 \%)\end{array}$ & $\begin{array}{l}1 \\
(7,1 \%)\end{array}$ & - & $\begin{array}{l}14 \\
(100 \%)\end{array}$ \\
\hline & \begin{tabular}{|l|} 
TOTAL \\
WOMEN
\end{tabular} & $\begin{array}{l}111 \\
(42,2 \%)\end{array}$ & \begin{tabular}{|l|}
62 \\
$(23,6 \%)$
\end{tabular} & $\begin{array}{l}26 \\
(9,9 \%)\end{array}$ & $\begin{array}{l}25 \\
(9,5 \%)\end{array}$ & \begin{tabular}{|l|}
39 \\
$(14,8 \%)$
\end{tabular} & $\begin{array}{l}263 \\
(100 \%)\end{array}$ \\
\hline \multirow[t]{7}{*}{$\begin{array}{l}\text { Male } \\
\text { Characters }\end{array}$} & Male Chorus & $\begin{array}{l}28 \\
(54,9 \%)\end{array}$ & $\begin{array}{l}11 \\
(21,6 \%)\end{array}$ & $\begin{array}{l}1 \\
(2 \%) \\
\end{array}$ & $\begin{array}{l}9 \\
(17,6 \%)\end{array}$ & $\begin{array}{l}2 \\
(3,9 \%)\end{array}$ & $\begin{array}{l}51 \\
(100 \%)\end{array}$ \\
\hline & Magistrate & $\begin{array}{l}10 \\
(38,5 \%)\end{array}$ & $7(26,9 \%)$ & $\begin{array}{l}1 \\
(3,8 \%)\end{array}$ & $\begin{array}{l}2 \\
(7,7 \%)\end{array}$ & $6(23,1 \%)$ & $26(100 \%)$ \\
\hline & Kinesias & $\begin{array}{l}24 \\
(66,7 \%)\end{array}$ & $\begin{array}{l}9 \\
(25 \%)\end{array}$ & $\begin{array}{l}1 \\
(2,8 \%) \\
\end{array}$ & - & \begin{tabular}{|l|}
2 \\
$(5,6 \%)$ \\
\end{tabular} & $36(100 \%)$ \\
\hline & Spartan Herald & $\begin{array}{l}3 \\
(100 \%)\end{array}$ & - & - & - & - & $\begin{array}{l}3 \\
(100 \%)\end{array}$ \\
\hline & Spartan Men ${ }^{19}$ & $\begin{array}{l}13 \\
(92,9 \%)\end{array}$ & - & - & $\begin{array}{l}1 \\
(7,1 \%)\end{array}$ & - & $14(100 \%)$ \\
\hline & Athenian Men & $\begin{array}{l}5 \\
(25 \%) \\
\end{array}$ & $\begin{array}{l}3 \\
(15 \%) \\
\end{array}$ & $\begin{array}{l}2 \\
(10 \%)\end{array}$ & $\begin{array}{l}6 \\
(30 \%) \\
\end{array}$ & \begin{tabular}{|l|}
4 \\
$(20 \%)$ \\
\end{tabular} & $20(100 \%)$ \\
\hline & TOTAL MEN & $\begin{array}{l}83 \\
(55,3 \%)\end{array}$ & $\begin{array}{l}30 \\
(20 \%)\end{array}$ & \begin{tabular}{|l|}
5 \\
$(3,3 \%)$
\end{tabular} & $\begin{array}{l}18 \\
(12 \%)\end{array}$ & $14(9,4 \%)$ & $\begin{array}{l}150 \\
(100 \%)\end{array}$ \\
\hline TOTAL & & $194(47 \%)$ & $\begin{array}{l}92 \\
(22,3 \%)\end{array}$ & $31(7,5 \%)$ & $\begin{array}{l}43 \\
(10,4 \%)\end{array}$ & \begin{tabular}{|l|}
53 \\
$(12,8 \%)$
\end{tabular} & $\begin{array}{l}413 \\
(100 \%)\end{array}$ \\
\hline
\end{tabular}

Table 1. Personal pronouns (tokens and percentage) in the comedy Lysistrata

\begin{tabular}{|l|l|l|l|l|l|l|l|}
\hline & & I & You sg. & We incl. & We excl. & You pl. & Total \\
\hline $\begin{array}{l}\text { Female } \\
\text { characters }\end{array}$ & Praxagora (f) & $\begin{array}{l}25 \\
(40,3 \%)\end{array}$ & $\begin{array}{l}17 \\
(27,4 \%)\end{array}$ & $\begin{array}{l}6 \\
(9,7 \%)\end{array}$ & $\begin{array}{l}4 \\
(6,5 \%)\end{array}$ & $\begin{array}{l}10 \\
(16,1 \%)\end{array}$ & $\begin{array}{l}62 \\
(100 \%)\end{array}$ \\
\hline & $\begin{array}{l}\text { Praxagora } \\
\text { disguised (m) }\end{array}$ & $\begin{array}{l}3 \\
(42,9 \%)\end{array}$ & - & $2(28,6 \%)$ & - & $2(28,6 \%)$ & $\begin{array}{l}7 \\
(100 \%)\end{array}$ \\
\hline & 1st Woman & $\begin{array}{l}8 \\
(53,3 \%)\end{array}$ & $\begin{array}{l}6 \\
(40 \%)\end{array}$ & $\begin{array}{l}1 \\
(6,7 \%)\end{array}$ & - & - & $\begin{array}{l}15 \\
(100 \%)\end{array}$ \\
\hline & 2nd Woman & $\begin{array}{l}9 \\
(81,8 \%)\end{array}$ & - & $2(18,2 \%)$ & - & - & $\begin{array}{l}11 \\
(100 \%)\end{array}$ \\
\hline & Female Chorus & $\begin{array}{l}5 \\
(21,7 \%)\end{array}$ & $5(21,7 \%)$ & $\begin{array}{l}10 \\
(43,5 \%)\end{array}$ & $\begin{array}{l}3 \\
(13 \%)\end{array}$ & - & $\begin{array}{l}23 \\
(100 \%)\end{array}$ \\
\hline & Female Herald & - & - & - & - & 1 & 1 \\
\hline
\end{tabular}

19 The characters indicated as "Spartan Men", “Athenian Men”, and "Other Women” in Lys. represent the union of the lines of different characters variously identified as "First Spartan Man", "Second Spartan Man", and so on. It is quite impossible to establish how many men (or women) were on stage, or which lines were spoken by which character (see Henderson 1987). 


\begin{tabular}{|c|c|c|c|c|c|c|c|}
\hline & & & & & & $(100 \%)$ & $(100 \%)$ \\
\hline & Girl & $\begin{array}{l}10 \\
(45,5 \%)\end{array}$ & \begin{tabular}{|l|}
12 \\
$(54,5 \%)$
\end{tabular} & - & - & - & \begin{tabular}{|l|}
22 \\
$(100 \%)$
\end{tabular} \\
\hline & 1st Old Woman & $\begin{array}{l}22 \\
(56,4 \%)\end{array}$ & $\begin{array}{l}16 \\
(41 \%)\end{array}$ & - & $\begin{array}{l}1 \\
(2,6 \%)\end{array}$ & - & \begin{tabular}{|l|}
39 \\
$(100 \%)$
\end{tabular} \\
\hline & 2nd Old Woman & $\begin{array}{l}7 \\
(50 \%)\end{array}$ & $\begin{array}{l}7 \\
(50 \%)\end{array}$ & - & - & - & \begin{tabular}{|l|}
14 \\
$(100 \%)$
\end{tabular} \\
\hline & 3rd Old Woman & $\begin{array}{l}2 \\
(40 \%)\end{array}$ & $\begin{array}{l}3 \\
(60 \%)\end{array}$ & - & - & - & \begin{tabular}{|l|}
5 \\
$(100 \%)$
\end{tabular} \\
\hline & Female Servant & $\begin{array}{l}4 \\
(44,4 \%)\end{array}$ & $3(33,3 \%)$ & - & $1(11,1 \%)$ & $1(11,1 \%)$ & \begin{tabular}{|l|}
9 \\
$(100 \%)$
\end{tabular} \\
\hline & \begin{tabular}{|l|} 
TOTAL \\
WOMAN
\end{tabular} & $\begin{array}{l}95 \\
(45,7 \%)\end{array}$ & \begin{tabular}{|l|}
69 \\
$(33,2 \%)$
\end{tabular} & $\begin{array}{l}21 \\
(10,1 \%)\end{array}$ & $\begin{array}{l}9 \\
(4,3 \%)\end{array}$ & $\begin{array}{l}14 \\
(6,7 \%)\end{array}$ & \begin{tabular}{|l|}
208 \\
$(100 \%)$
\end{tabular} \\
\hline \multirow[t]{6}{*}{$\begin{array}{l}\text { Male } \\
\text { characters }\end{array}$} & Blepyrus & $36(72 \%)$ & $\begin{array}{l}9 \\
(18 \%)\end{array}$ & $\begin{array}{l}2 \\
(4 \%)\end{array}$ & $\begin{array}{l}2 \\
(4 \%)\end{array}$ & $\begin{array}{l}1 \\
(2 \%)\end{array}$ & $\begin{array}{l}50 \\
(100 \%) \\
\end{array}$ \\
\hline & Neighbour & $\begin{array}{l}6 \\
(54,5 \%)\end{array}$ & $5(45,5 \%)$ & - & - & - & \begin{tabular}{|l|}
11 \\
$(100 \%)$
\end{tabular} \\
\hline & Chremes & $\begin{array}{l}14 \\
(38,9 \%)\end{array}$ & $\begin{array}{l}16 \\
(44,4 \%)\end{array}$ & \begin{tabular}{|l|}
3 \\
$(8,3 \%)$
\end{tabular} & \begin{tabular}{|l|}
3 \\
$(8,3 \%)$
\end{tabular} & - & \begin{tabular}{|l|}
36 \\
$(100 \%)$
\end{tabular} \\
\hline & Sceptic Man & $\begin{array}{l}6 \\
(60 \%) \\
\end{array}$ & $\begin{array}{l}3 \\
(30 \%) \\
\end{array}$ & $\begin{array}{l}1 \\
(10 \%)\end{array}$ & - & - & \begin{tabular}{|l}
10 \\
$(100 \%)$ \\
\end{tabular} \\
\hline & Boy & $\begin{array}{l}24 \\
(61,5 \%)\end{array}$ & $\begin{array}{l}14 \\
(35,9 \%)\end{array}$ & - & - & $\begin{array}{l}1 \\
(2,6 \%)\end{array}$ & \begin{tabular}{|l|}
39 \\
$(100 \%)$
\end{tabular} \\
\hline & TOTAL MEN & $\begin{array}{l}86 \\
(58,9 \%)\end{array}$ & \begin{tabular}{|l}
47 \\
$(32,2 \%)$
\end{tabular} & $\begin{array}{l}6 \\
(4,1 \%)\end{array}$ & \begin{tabular}{|l|}
5 \\
$(3,4 \%)$
\end{tabular} & $\begin{array}{l}2 \\
(1,4 \%)\end{array}$ & \begin{tabular}{|l|}
146 \\
$(100 \%)$
\end{tabular} \\
\hline TOTAL & & $\begin{array}{l}181 \\
(51,1 \%)\end{array}$ & $\begin{array}{l}116 \\
(32,8 \%)\end{array}$ & $\begin{array}{l}27 \\
(7,6 \%)\end{array}$ & $\begin{array}{l}14 \\
(4 \%)\end{array}$ & $16(4,5 \%)$ & \begin{tabular}{|l|}
354 \\
$(100 \%)$
\end{tabular} \\
\hline
\end{tabular}

Table 2. Personal pronouns (tokens and percentage) in the comedy Ecclesiazusae

As for the gender difference in the use of PPs, a pattern of variation may be detected just from these rough calculations: Male characters in Eccl., including Praxagora in disguise, show indeed a preference for 1st person singular pronouns. For instance, Blepyrus produces 50 pronouns in total, with 36 first person singular pronouns, which makes him the character with the highest number of PPs, after the protagonist. In Lys., however, male characters utter few PPs, excepting Kinesias ${ }^{20}$ and the Male Chorus ${ }^{21}$.

These first considerations were confirmed by looking at the percentages of PPs use. Generally speaking, the 1st person singular pronoun shows the highest percentage of use in both comedies, even if this value is slightly higher in Eccl. (51\%) than in Lys. $(47 \%)$. In both texts 2 nd person singular pronouns are also well attested, again with a higher value in Eccl. (32.8\%) than in Lys. (22.3\%). An important difference between the two comedies can be observed concerning plural pronouns: Lys. shows a high value of 2nd person plural pronouns $(12.8 \%)$ and of 1 st person plural pronouns with an exclusive value (10.4\%), whereas these values are significantly lower in Eccl. (4.5\% and 4\%, respectively). One possible explanation may be that in Eccl. most dialogues are between

${ }^{20}$ Henderson (1987: 174) points out that Kinesias is the only man to be explicitly named in this

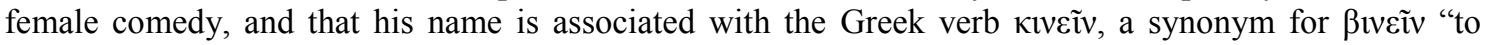
fuck". Kinesias is thus immediately associated with the sexual sphere since he first appears on stage, and he then repeatedly tries to persuade his wife Myrrhine to have sex with him in one of the most hilarious scene in the whole comedy (865-951). See also Olson (1992).

${ }^{21}$ The chorus sometimes uses also singular personal pronouns, because it is usually considered as a single character. 
single characters, while in Lys. the conflict that needs to be resolved is between groups of speakers.

As for single characters, leaving apart those cases referring to minor characters, the data shows a gender-based variation in the use of PPs. In fact, in both comedies male characters prefer 1 st person singular pronouns, with the highest percentage shown by Blepyrus (72\%), the Boy (61.5\%), the Sceptic Man (60\%) and the Neighbour (54.5\%) in Eccl., and by Spartan Men (92.9\%) and Kinesias (66.7\%) in Lys. An exception is represented by Chremes in Eccl. and by the Athenian Men in Lys.: They both show high percentages of use of 1st person singular pronouns $(38.9 \%$ and $25 \%$ respectively), but Chremes also utters many 2nd person singular pronouns (44.4\%), while Athenian Men also use many 1st person plural pronouns with an exclusive value $(30 \%)$. On the contrary, female characters only show a slight preference for 2 nd person singular pronouns (e.g., Kalonike $23.1 \%$ in $L y s$ ). Moreover, the highest percentages of use of 1st person plural pronouns with an inclusive value are shown by female characters, in particular by Kalonike in Lys. (30.8\%) and by the Female Chorus in Eccl. $(43.5 \%)$.

This distinction between male and female characters becomes more evident when considering PPs as markers of communicative styles, following Tannen's (1990) distinction between report-speaking and rapport-speaking communicative style (see section 3). As previously illustrated, PPs of 1st person singular, 2nd person plural and 1 st person plural with an exclusive value have been considered as markers for reportspeaking communicative style, whereas 2nd person singular and 1st person plural pronouns with an inclusive value are markers for rapport-speaking communicative style. Fig. 1 and 2 illustrate the distribution of these communicative styles in the two comedies $^{22}$.

Almost all characters show a preference for the report-speaking style, even if it is possible to observe some differences between male and female characters. In fact, in both comedies men prefer the report-speaking communicative style, whereas the highest percentages of rapport-speaking communicative style could be found for female characters. For instance, in Lys. Kalonike uses a rapport-speaking style with a percentage of $53.8 \%$, which is the highest percentage of the whole comedy, and in Eccl. the highest percentages of use of the rapport-speaking style are shown by the Female Chorus $(65.9 \%)$, the $3^{\text {rd }}$ Old Woman $(60 \%)$, and the Girl $(54.5 \%)$. In this respect, the male character Chremes represents an exception, since he shows a slight preference for the rapport-speaking style $(52.8 \%)^{23}$.

${ }^{22}$ The characters' sex is indicated between brackets only in case of characters with a proper name. A star $(*)$ signals those characters with less than 10 PPs.

${ }^{23}$ Even considering that Chremes is involved in a scene belonging to the "chatting" framework (see 4.2.2), this does not seem to fully justify the exceptionality of his high use of rapport-speaking communicative style. 


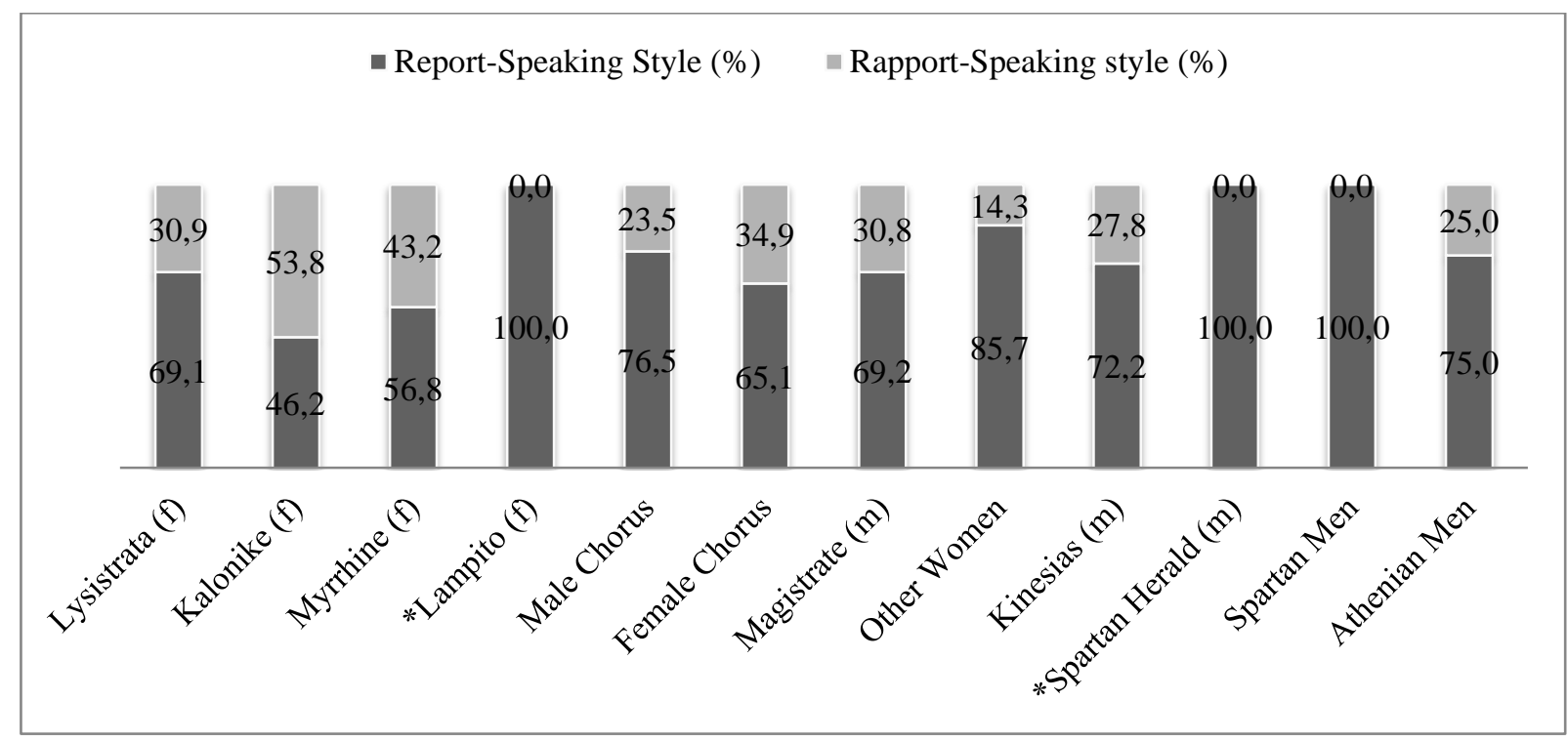

Fig. 1. Percentage of communicative styles' variation in Lysistrata

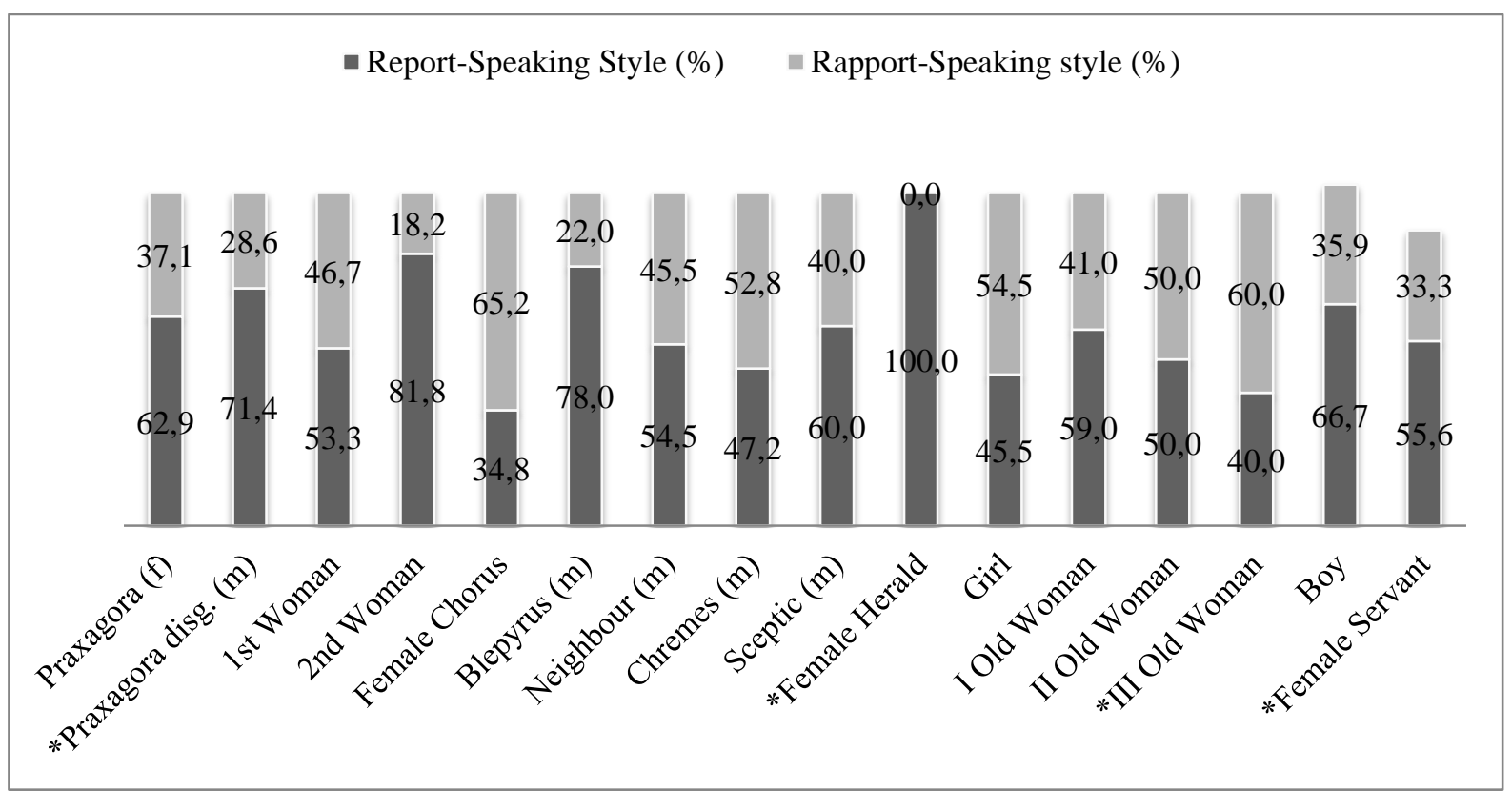

Fig. 2. Percentages of communicative styles' variation in Ecclesiazusae

Another interesting point concerns the two female leaders. Both Lysistrata and Praxagora show a high percentage of use of the report-speaking style $(69.1 \%$ and $62.9 \%$ respectively). Praxagora's percentage of use of the report-speaking communicative style increases slightly when she is disguised as a man (71.4\%). This fact can add value to the previous consideration that male characters prevalently use a report-speaking communicative style, whereas female characters show a higher variability with a slight preference for rapport-speaking communicative style. 


\subsubsection{The protagonists}

Obviously, Lysistrata and Praxagora are the main characters, and they utter many PPs in different scenes ${ }^{24}$. This section focuses on variation in PPs use and communicative style in the speech of the two female protagonists ${ }^{25}$.

Lysistrata appears in many scenes, as it is evident from Tab. 3 (for PPs use) and Fig. 3 (for communicative style). However, many tokens belong to only two scenes (i.e., lines 1-253 and lines 430-613). In the first scene, within a chatting framework, Lysistrata often uses 1st person plural pronouns with an inclusive value $(21.3 \%)$, but she clearly prefers 1st person singular pronouns $(36.2 \%)$ and 2 nd person singular pronouns $(23.4 \%)$. On the other hand, during a scene classified as belonging to the fighting framework (lines 430-613), Lysistrata's use of plural PPs increases: 1st person plural pronouns with an exclusive value occur in $32.6 \%$ of the cases, and 2 nd person plural pronouns show a similar percentage $(30.3 \%)$. 2nd person plural pronouns are also very frequent $(52.9 \%)$ in one of the last scenes of the comedy (lines 1112-1188), again a fighting framework.

\begin{tabular}{|c|c|c|c|c|c|c|}
\hline Lines & I & You sg. & We incl. & We Excl. & You pl. & Total \\
\hline vv. $1-253$ & $17(36.2 \%)$ & $\begin{array}{l}11 \\
(23.4 \%)\end{array}$ & $10(21.3 \%)$ & $\begin{array}{l}3 \\
(6.4 \%)\end{array}$ & $6(12.8 \%)$ & $47(100 \%)$ \\
\hline vv. 430-613 & $\begin{array}{l}7 \\
(16.4 \%)\end{array}$ & $7(16.4 \%)$ & $\begin{array}{l}2 \\
(4.3 \%)\end{array}$ & $14(32.6 \%)$ & $13(30.3 \%)$ & $43(100 \%)$ \\
\hline vv. 708-780* & $\begin{array}{l}2 \\
(50 \%)\end{array}$ & $\begin{array}{l}1 \\
(25 \%)\end{array}$ & $\begin{array}{l}1 \\
(25 \%)\end{array}$ & - & - & $4(100 \%)$ \\
\hline vv. 829-864 & $\begin{array}{l}4 \\
(40 \%)\end{array}$ & $\begin{array}{l}4 \\
(40 \%)\end{array}$ & - & $\begin{array}{l}1 \\
(10 \%)\end{array}$ & $\begin{array}{l}1 \\
(10 \%)\end{array}$ & $10(100 \%)$ \\
\hline vv. 1112-1188 & $\begin{array}{l}6 \\
(35.3 \%)\end{array}$ & $\begin{array}{l}1 \\
(5.9 \%)\end{array}$ & - & $\begin{array}{l}1 \\
(5.9 \%)\end{array}$ & $9(52.9 \%)$ & $17(100 \%)$ \\
\hline vv. 1273-1295* & - & $\begin{array}{l}1 \\
(50 \%)\end{array}$ & - & - & $\begin{array}{l}1 \\
(50 \%)\end{array}$ & $\begin{array}{l}2 \\
(100 \%)\end{array}$ \\
\hline TOTAL & $36(29.6 \%)$ & $\begin{array}{l}25 \\
(20.3 \%)\end{array}$ & $13(10.5 \%)$ & $19(15.3 \%)$ & $30(24.3 \%)$ & $\begin{array}{l}123 \\
(100 \%)\end{array}$ \\
\hline
\end{tabular}

Tab. 3. Lysistrata's use of PPs (tokens and percentages)

These percentages of PPs use clearly correlate with the communicative styles adopted by the protagonist throughout the comedy. Fig. 3 highlights how Lysistrata always prefers a report-speaking style, with the highest values reached at lines 430-613 (79.1\%) and 1112-1188 (94.1\%), the fighting frameworks. In two other scenes, however, Lysistrata selects a rapport-speaking communicative style, with a percentage of $44.7 \%$ at lines 1-253, and of 50\% at lines 708-780. It is interesting to note that these scenes are the only ones involving Lysistrata on stage among other women and without any men (see section 4.3).

\footnotetext{
${ }^{24}$ For a detailed analysis of the division of the scenes, see Meluzzi (2010).

${ }^{25}$ We consider only the cases in which Praxagora is on stage as herself, thus not counting those instances of PPs in those lines spoken by the protagonist in male disguise, even if this is limited to few lines with 7 PPs in total.
} 


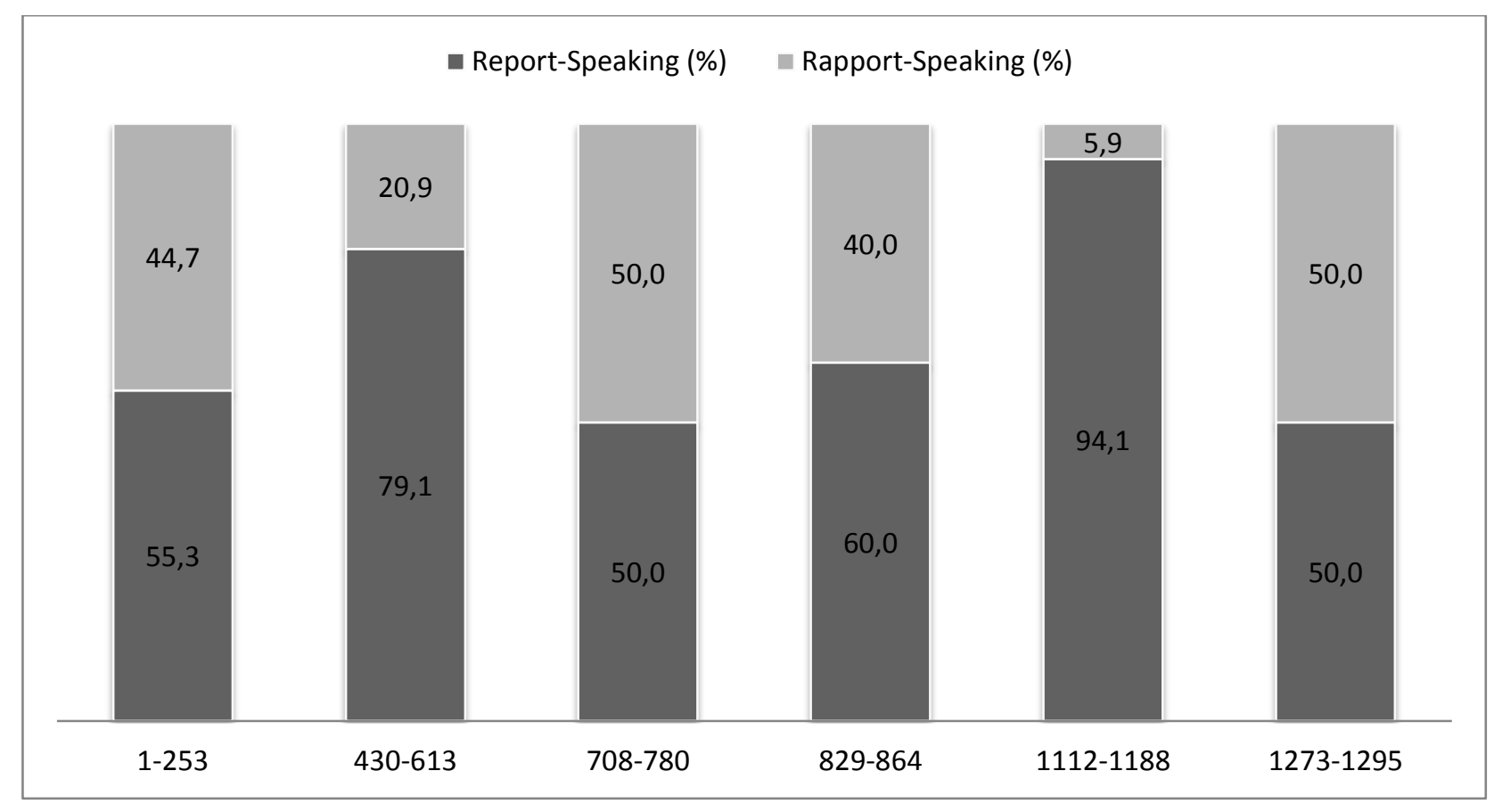

Fig. 3. Percentage of Lysistrata's communicative styles

In Eccl., Praxagora is on stage in only three scenes, which could basically be reduced to two, by summing up the instances of PPs at lines 1-284 with the instances at lines 504$519^{26}$. PPs vary significantly in Praxagora's use, and this is particularly evident for $1 \mathrm{st}$ person pronouns, both singular and plural. In the first part of the comedy, Praxagora uses 1st person plural pronouns only with an inclusive value, whereas in the last part of the comedy she uses only 1 st person plural pronouns with an exclusive value. As for 1 st person singular, she selects these PPs in $31 \%$ of the cases in the first part of the comedy, but this percentage increases to $48.5 \%$ in the second part. On the other hand, the use of 2nd person plural pronouns decreases from $24.2 \%$ in the first scenes to $9.1 \%$ in the second scene. Only the use of 2 nd person singular pronouns remains quite high in both scenes, even with a slight rise in the last part of the comedy.

${ }^{26}$ One may argue against this choice, maybe supposing that the switch in Praxagora's use of PPs and communicative style between the two main scenes could be contrasted here. As a matter of fact the second scene is very short (only 15 lines) and presents only few instances of PPs. Moreover, referring back to Hymes's (1974) model, it is possible to argue that the communicative contexts of these two scenes are very similar, since they involve only female characters who try to make an agreement. In fact, in the first scene (lines 1-284) women are discussing among themselves how to gain the power, and in the following section (lines 504-519) they return on stage to discuss what to do next, before leaving Praxagora alone with her husband Blepyrus and his friend Chremes (lines 520 and following). Previously, in lines 285-503, the characters of Blepyrus and Chremes had been introduced, and this section represents a separate sequence, including a different chatting framework (see 4.2.2). All considered, it seems legitimate to consider the instances of PPs at lines 504-519 together with the instances of lines 1-284, and considering these two sections as one scene (see also Meluzzi 2010). 


\begin{tabular}{|l|l|l|l|l|l|l|}
\hline Lines & I & You sg. & We incl. & We excl. & You pl. & Total \\
\hline vv. 1-284; & 9 & 7 & 6 & 0 & 7 & 29 \\
$504-519$ & $(31 \%)$ & $(24.1 \%)$ & $(20,7 \%)$ & $(0 \%)$ & $(24,2 \%)$ & $(100 \%)$ \\
\hline & 16 & & 0 & 4 & 3 & 33 \\
vv. 520-724 & $(48.5 \%)$ & $10(30.3 \%)$ & $(0 \%)$ & $(12.1 \%)$ & $(9.1 \%)$ & $(100 \%$ \\
\hline & 25 & & 6 & 4 & 10 & 62 \\
TOTALE & $(40.3 \%)$ & $17(27.4 \%)$ & $(9.7 \%)$ & $(6.5 \%)$ & $(16.1 \%)$ & $(100 \%)$ \\
\hline
\end{tabular}

Tab. 4. Praxagora's use of PPs (tokens and percentages)

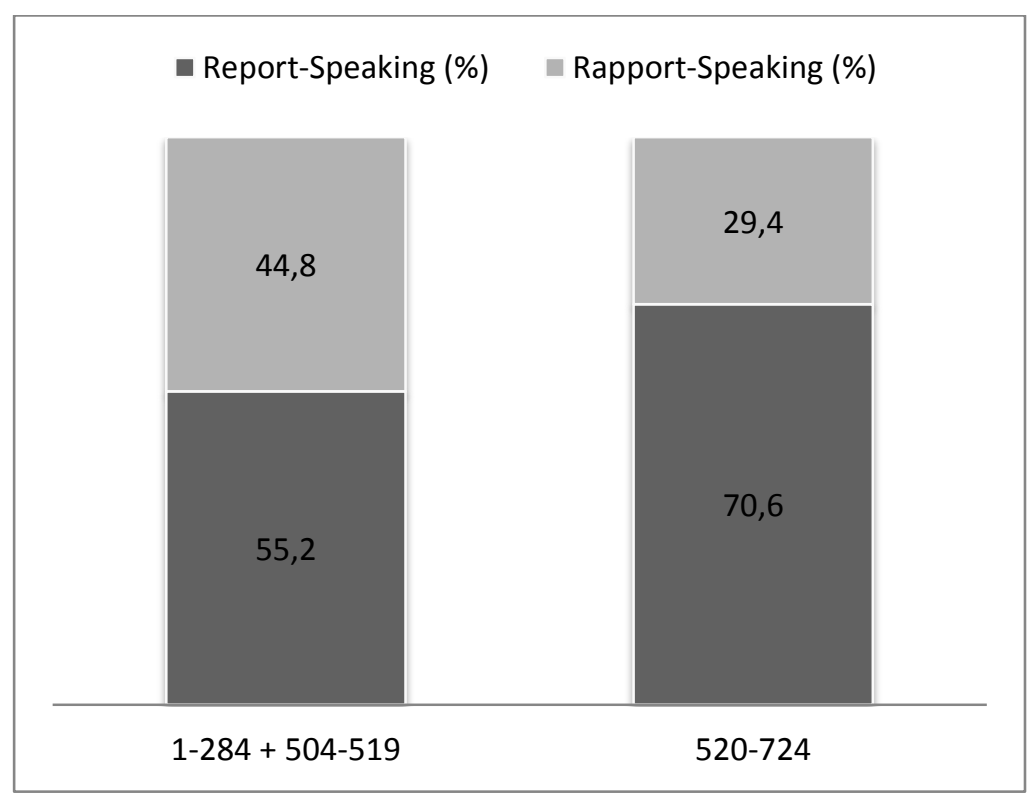

Fig. 4. Praxagora's communicative styles

The difference observed in PPs use is reflected in communicative styles' variation (Fig. 4). Even if Praxagora always prefers a report-speaking communicative style, her use increases from the first scenes $(55.2 \%)$ to the last, reaching $70.6 \%$ of occurrences. On the other hand, her use of a rapport-speaking communicative style is quite high in the first scenes $(44.8 \%$ ) but it decreases to $29.4 \%$ at lines $520-724$. It is interesting to note that the first scenes involve only female characters, whereas in the last scene Praxagora is alone on stage against two men.

The comparison of PPs and communicative styles in the lines of the two protagonists allows some considerations. Both Lysistrata and Praxagora usually select 1st personal singular pronouns, and a report-speaking communicative style. An interesting variation emerges concerning plural pronouns, and in particular the use of 1st person plural pronouns with an inclusive or an exclusive value: The protagonists clearly play with the possible values of the 1 st person plural pronoun according to the hearer (i.e., women vs. men). These differences are, however, more evident in Praxagora's than Lysistrata's use of PPs, maybe due to textual reasons (i.e., the great fragmentation of scenes in Lys. if compared to Eccl.). 


\subsection{PPs for fighting and for chatting}

The first part of the analysis moved from texts to data, whereas this second part will move from data back to the texts, by considering some instances of pragmatic use of PPs in the two different communicative frameworks labelled as "fighting" and chatting". In the two comedies it is possible to detect five scenes of "fighting" (Lys. 430-613, Lys. 1112-1188, Eccl. 520-724, Eccl. 746-876, and Eccl. 884-937), and three of "chatting" (Lys. 1-253, Eccl. 1-284, and Eccl. 372-477). Each scene is analysed by considering PPs use in context, and by referring to Bravo's (1999) categories of autonomía and afiliación. Short quotations are provided ${ }^{27}$ for those cases involving possible referential ambiguities.

\subsubsection{The fighting framework}

The five scenes belonging to the "fighting framework" are characterized by the verbal and sometimes also physical opposition among characters on stage, and by the presence of FTAs. Three scenes involve speakers of opposite genders (Lys. 430-613, Lys. 11121188, and Eccl. 520-724), while the other two (Eccl. 746-876, and Eccl. 884-937) involve speakers of the same gender.

In Lys. 430-613, the protagonist opposes the Magistrate, who wants to know her plan for saving Greece. The Magistrate firstly addresses Lysistrata with a 2nd person singular pronoun (gr. sý), as in (1), by calling her a mischievous woman, thus not recognizing her as the leader of a group, as it is also evident in his use of forms of address (e.g., miarà 'villainous woman') ${ }^{28}$.

(1) (Lys. 433)

433 Pr. álēthes, õ miarà sý; pồ 'sti toxótēs;

Mag. How dare you, you (sg.) villainous woman! Where's an archer?

However, in line 493 Lysistrata introduces a 1st person plural pronoun (gr. hēmeîs), referring to both herself and the other women but clearly excluding the Magistrate: This is an instance of 1st person plural pronoun with an exclusive value. Moreover, by using a 1st plural pronoun, Lysistrata is not posing herself as a lonely rebel, but as the leader of the female group. In his reply, the Magistrate uses a 2nd person plural pronoun (gr. hymeîs), thereby accepting Lysistrata's claim to be the leader of the women of Athens. Moreover, the combined use of these two plural pronouns continues for a couple of lines, as shown in (2).

${ }^{27}$ Examples are quoted from Wilson's (2007) critical edition, transliterated from Greek fonts. For each example, the English translation is based on Sommerstein (1990) for Lys. and Sommerstein (1998) for Eccl., as it has been previously mentioned in section 2. Pronouns are underscored both in the Greek and in the English text; a special indication is provided in the translation of 2nd person pronouns, thus indicating if they translate an original 2nd person singular (sg.) or plural (pl.). Since Greek is a prodrop language (see section 2 the English translation sometimes introduces PPs lacking in the original Greek texts; when this happens, PPs in the English text are not underscored.

${ }^{28}$ For a pragmatic analysis of forms of address in these texts see Meluzzi (2014). 
(2) (Lys. 493-8)

493 Pr. allà tí dráseis;

Mag. But what are you doing?

493 Lys. toûtó m'erōtâis? hēmeîs tamieúsomen autó.

Lys. You ask me that? We (excl.) will manage it (the money) for you.

494 Pr. hymeîs tamieúsete targýrion;

Mag. You (pl.)'ll manage the money?

$494^{29}$ Lys. $\quad t \grave{<}<$ dè $>$ deinòn toûto nomízeis;

Lys. Why do you think that so strange?

495 ou kaì tándon chrēmata pántōs hēmeîs tamieúomen hymîn;

Don't we (excl.) manage the household finances for you (pl.) already?

496 Pr. all'ou tautón.

Mag. But it's not the same thing.

496 Lys. pō̄s ou tautón;

Lys. Why is it not the same thing?

496 Pr. polemètéon ést'apò toútou.

Mag. This money needs to be used for the war.

497 Lys. all'oudèn deî prôton polemeîn.

Lys. But you shouldn't be making war at all in the first place.

$497 \quad$ Pr. pỗs gàr sōthēsómeth'állōs;

Mag. How else can we keep ourselves safe?

498 Lys. hèmeîs hymâs sốsomen.

Lys. $\quad$ We (excl.) will see you (pl.) safe.

498 Pr. hymêts;

Mag. You (pl.)?

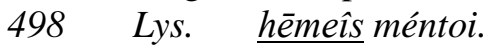

Lys. Yes, $\underline{\text { us. }}$.

$498 \quad$ Pr. schétlión ge.

Mag. The audacity!

Since the quarrel is between Lysistrata and the Magistrate, one may have expected an increase in the use of 1st and 2nd person singular pronouns, but after line 493 both Lysistrata and the Magistrate switch to plural pronouns. It is noteworthy that plural pronouns here do not show any referential ambiguity: Lysistrata is surrounded by other women and the Magistrate by the Men of the Chorus, and instances of plural pronouns could be easily interpreted as referring to the two groups. As said, this interpretation is first introduced by Lysistrata, and then is also accepted by the Magistrate. This represents a clear pragmatic use of PPs: In fact, the use of 1st and 2nd person plural pronouns creates two opposite groups (i.e., women's vs. men's group). Put differently, by choosing the plural instead of the singular PPs, Lysistrata emphasizes her afiliación to the women's group, and at the same time she marks her and her followers' autonomía from the men's group.

However, almost at the end of this verbal fight, Lysistrata switches again to singular PPs: She uses many 1st person singular pronouns while explaining her plan for the good administration of the town, and how she has developed this plan (lines 506520). But when she speaks of the present state of her plan, she switches back to 1 st and

${ }^{29}$ It was not uncommon in Ancient Greek comedy and tragedy to divide one line among different characters; see also Hughes (2011). 
2nd person plural pronouns, thus marking again the unity of the women's group as opposed to the men's group.

A different situation occurs in the second fighting scene in Lys. 1112-1188, when the protagonist is on stage arguing against Athenian and Spartan men. Lysistrata is now presented as the victorious leader of the female revolution, but she still has to persuade the men to find an agreement on the conditions of peace. In her speech, Lysistrata uses 2nd person plural pronouns, but it is remarkable how often she uses the 1st person singular pronoun (gr. eg⿳亠丷厂, moi), as for instance in (3):

(3) (Lys. 1124)

1124 Lys. egō gunè mén eimi, noûs d'énestí moi.

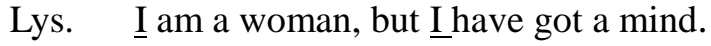

Lysistrata uses both 2nd person plural and 1st person singular pronouns to mark her autonomía from her addressees, and she also portrays herself as the leader who has stopped the war between Athens and Sparta.

A similar situation occurs in the fighting scene in Eccl. 520-724, when Praxagora argues with her husband Blepyrus and his friend Chremes. Despite the similarities of the setting and the gender of the participants involved in the interaction, Praxagora's use of PPs is quite peculiar, as shown in (4).

(4) (Eccl. 596-600)

596 Prax. mà Dí', all'ephthēs m'hypokroúsas.

Prax. No, no, you jumped in too soon with your interruption ${ }^{30}$;

597 toûto gàr émellon egò̀ léxein: tè̀n gên prốtista poiếsō that was just what I was going to say. In the first place, I shall make land

598 koinèn pántōn kai targýrion kaì táll'hopós'estìn hekástỗi. the common property of all, and money, and everything else that every ndividual possesses; eît'apò toútōn koinōn óntōn hēmeîs boskésomen hymâs then, from this common stock, we (excl.) women will maintain you (pl.), tamieuómenai kaì pheidómenai kaì tè̀n gnốmēn proséchousai. applying our intelligence to manage it economically.

Note that the Greek text in line 599 shows the pronoun alone, whereas in his translation Sommerstein (1998: 89) specifies that this 1st person plural pronoun is referring to the women's group. Although the pronominal reference can be easily inferred from the context, Sommerstein prefers to clarify this reference, but interestingly he does not do the same for the 2nd person plural pronoun (gr. hymâs) in the very same line. One possible explanation is that both pronouns are ambiguous here, but one is to some extent more ambiguous than the other: As soon as the first is disambiguated, the latter can be inferred to by conversational implicature. As a matter of fact, in this textual portion Praxagora speaks to two men, and she utters first a 1st person singular pronoun (gr. $m e$ ), then 1st and 2nd person plural pronouns (gr. hèmeîs, hymâs). Since she is the only woman on stage, her use of a 1st person plural pronoun may be interpreted as a pragmatic marker for her autonomía from her addressees, and her afiliación to another

${ }^{30}$ The Greek text has a 1st person singular pronoun me; a better translation might have been "you interrupted too soon while I was speaking". 
group. This other group is not further specified, even if the context suggests that she is referring to the women's group. In this sense, Sommerstein's translation makes this reference explicit. On the other hand, the 2 nd person plural pronoun could refer both to the addressees (i.e. Blepyrus and Chremes) or, more generically, to a larger group of men. Since this pronominal reference is far more ambiguous than the previous one, Sommerstein (1998) prefers not to make it explicit, leaving the interpretation to the reader. However, it seems legit to see in Praxagora's speech the verbal creation and opposition of two groups (i.e., men's group and women's group). This pragmatic use of PPs is thus similar to the one discussed for Lysistrata in (2).

In the other two scenes belonging to the fighting framework (Eccl. 746-876 and Eccl. 884-937) the quarrel involves speakers of the same gender. In both cases the speaker wants to obtain something from his/her addressee: In the first case, Chremes wants to persuade the Sceptic Man that the women's reforms are righteous ${ }^{31}$, while in the second case an old woman and a girl quarrel for the sexual favours of a young man. In this second verbal fight, the two female characters use many 1st and 2nd person singular pronouns, therefore reinforcing their FTAs, as shown in (5).

(5) (Eccl. 930-4)

930 Gr. tí moi dialégei;

OldW. Why do you keep talking to me?

$930 \quad$ Ne. $\quad$ sỳdè tí diakýpteis;

Girl And why do you (sg.) keep peeping out like that?

$930 \quad$ Gr. $\quad \underline{\text { egó }}$;

OldW. $\underline{\text { Me? }}$

$931 \quad$ áidō pròs emautèn Epigénei tōmōi phílōi.

I'm singing to myself a song to my boyfriend Epigenes.

932 Ne. $\quad$ soì gàr phílos tís estin állos è Gérēs;

Girl You (sg.)'ve got a boyfriend - apart from Geres, that is?

933 Gr. deíxei ge kaì soí. tacha gàr eîsin hōs emé.

OldW. He'll show you (sg.). He's going to come to me in a moment.

In conclusion, in the fighting framework it is possible to notice how PPs use mainly marks the autonomía of the speaker from his/her addressee, in particular by using 1st person singular pronouns and 1st plural pronouns with an exclusive value, sometimes altogether with 2nd person plural pronouns.

\subsubsection{The chatting framework}

The three scenes belonging to the chatting framework (Lys. 1-253, Eccl. 1-284, and Eccl. 372-477) involve speakers of the same gender. In Lys. 1-253, women from many Greek towns come on stage, and the protagonist needs to persuade them to join her sex strike. Since the very beginning of the scene, Lysistrata uses 1st person plural pronouns with an inclusive value (e.g., line 10) in order to mark the afiliación within the women's group. Moreover, in her speech she places gender above ethnicity, thus encouraging women to see this affiliation as more important for their cause. However, Lysistrata's

31 Remember that Chremes is a male character, but he has been previously persuaded by Praxagora to accept the new female leadership, see (4). 
main aim is to force the group to follow her plan, thus naturally imposing herself as the leader of women's strike: For this pragmatic purpose, she also uses many 1st person singular pronouns, as in (6).

(6) (Lys. 111-112)

111 Lys. hethéloit'àn oûn, ei mēchanèn heúroim'egố,

Lys. If I were to find a plan, then, would you be willing

112 met'emô̂u katalŷsai tòn pólemon.

to join me in bringing the war to an end?

In the other comedy the situation is slightly different. In Eccl. 1-284 some Athenian women meet to refine their plan to speak in the Assembly, and some of them rehearse their speeches. After two unsatisfying attempts, Praxagora self-selected herself as the speaker and, to some extent, as the leader of the women's group ${ }^{32}$, as shown in (7).

(7) $($ Eccl. 169-171)

169 Prax. áperre kaì sỳ kaì káthēs'enteuthení.

Prax. Be off with you (sg.) ${ }^{33}$ too, and sit down away from here!

$170 \quad$ autè gàr hymō̄n g'héneká moi léxein dokõ

If this is what you (pl.) are like, I think I'm going

171

tondì laboûsa.

to take this and speak.

The protagonist uses both a 1st person singular pronoun (gr. moi) and a 2nd person plural pronoun (gr. hymōn): Praxagora is thus marking her afiliación to the women's group, but at the same time her authority as the possible leader. The other women acknowledge her leadership (lines 170-188): From now on, they refer to Praxagora with 2nd person singular and 1st person plural pronouns with an inclusive value (e.g., lines 260-261). Thus, the women pragmatically use PPs to emphasize the individuality and the authority of their new leader, whereas Praxagora stresses that she is still part of their group by using 1st person plural pronouns with an inclusive value.

The last scene belonging to the chatting framework (Eccl. 372-477) is very peculiar. This is the only case in these two comedies involving a calm speech between two men, Blepyrus and Chremes, thus involving two speakers and not two groups. Since Blepyrus missed the Assembly, Chremes reports to him what happened: An unknown speaker has suggested to give power to women, and the Assembly has agreed and nominated Blepyrus' wife, Praxagora, as the new leader of Athens. The two characters are marking their afiliación by using together 1st and 2nd person singular pronouns, as in line 444 with the expression sè kamè "you and me". However, some FTAs are still detectable in this scene, but they can be interpreted as an ironic joke, characterizing this male chat and differentiating it from the female ones. Blepyrus, indeed, cannot believe that his own wife is the new ruler of Athens, and Chremes does not waste the occasion to make fun of his friend's incredulity.

${ }^{32}$ Praxagora practises her speech in the women-only group, before going to the Athenian Assembly. It is assumed that this speech is the same that Praxagora is going to perform at the Assembly disguised as a man, but this scene is not included in the comedy.

${ }^{33}$ She is referring to the previous speaker, another woman who has performed a small speech full of mistakes. 
In conclusion, a common feature of the chatting framework is the speaker's aim to mark afiliación with his/her addressees. In this respect, the use of 1st person plural pronouns with an inclusive value is preferred, even if the combined use of 1st and 2nd person singular PPs shows the same pragmatic aim in case of conversation among two speakers only. Thus, variation in PPs use should be related to the context and, most of all, to the speaker's communicative goals.

\subsection{Summary of the results}

In the first part of the analysis it has been illustrated how gender influences the preference for one PP over the other, whereas in the second part of the analysis it has been shown how each pronoun may carry slightly different pragmatic values according to the communicative framework and the speakers' main aims. From these considerations it is possible to highlight some tendencies in the pragmatic use of Ancient Greek PPs in the two analysed comedies.

It is evident how male characters tend to be more report-speaking, and to use 1st person singular pronouns more frequently than female characters. On the other hand, the situation is more complex for female characters, even if Kalonike in Lys. and other minor characters in Eccl. show a preference for 2nd person singular pronouns, 1st person plural pronouns with an inclusive value, and a more rapport-speaking communicative style. These results generally agree with Hirschmann's (1994) considerations on the role of gender in the use of English PPs in conversation: She notices that men tend to use more 1st person singular pronouns, thus focusing the attention on the speaker; on the other hand, women prefer 1 st plural pronouns, thus including the addressee in their speech.

A relevant exception is the case of the two female leaders. As a matter of fact, both Lysistrata and Praxagora use many 1st person singular pronouns, and a mainly report-speaking communicative style. This more "male" communicative style adopted by the two protagonists should be justified by their role in the comedies: Since they are the leaders, they must hold the stage, exhibit knowledge and skills to rule their group of followers and achieve their goals. In this respect, it can be argued that both Lysistrata and Praxagora adapt their communicative style to a more male one (see Tannen 1990: 77), especially when they quarrel with male speakers. Thus, their social role as leaders modifies the protagonists' use of PPs: This adaptive pragmatic strategy seems to be common for female speakers in mixed groups, as it has been shown for other languages, and in particular for English (e.g., Holmes 1997; Tannen 1994).

Lysistrata and Praxagora's use of PPs varies throughout the comedy. In particular, two contexts may be identified as common for both the protagonists: In the first context the two leaders speak to other women in order to prepare the group for the future action (Lys. 1-253, Eccl. 1-284), whereas in the second context the leaders discuss with one or more male speakers (Lys. 430-613, Eccl. 520-724). These contexts have been associated to the chatting and the fighting frameworks, respectively. As shown in Fig. 3 and 4, both protagonists tend to increase their use of rapport-speaking communicative style in the chatting framework, while in the fighting framework they are sensibly more report-speaking. Differences between these two communicative 
frameworks also concern other linguistic elements, as, for instance, forms of address (see Meluzzi 2014).

Moreover, in the chatting framework the protagonists use different PPs with different pragmatic purposes. As a matter of fact, Lysistrata is a self-selected leader, and she has to persuade the other women to follow her: Thus, she uses many 1st person singular pronouns to establish her leadership, as well as 1st person plural pronouns to unify women's group. Her use of PPs may be summed up in terms of "I, Lysistrata, shall be your leader, and now we women shall do this and that". On the other hand, Praxagora self-selects only as a speaker in the rehearsal not as a leader of the group, and only after her performance the other women proposed her the leadership. In fact, the women have already jointly decided their plan and they were only looking for a spokeswoman to speak at the Assembly. Praxagora does not need to impose her leadership, and this behaviour is reflected in her preference for 1 st person plural pronouns with an inclusive value, instead of 1st person singular pronouns. PPs use in this chatting framework may thus be expressed in terms of "We women elect you, Praxagora, as our leader". Thus, in their use of PPs the two leaders show many similarities, while the few differences may be explained by the different communicative contexts and, most of all, by the leaders' main communicative goals.

\section{General discussion and conclusion}

In this paper, a corpus of two Aristophanes' comedies has been used to analyse PPs use in Ancient Greek. Working with this kind of data involves many philological problems, as was pointed out in section 2. Thus, a quantitative analysis is rather impossible for this kind of linguistic feature in only two texts. However, a qualitative approach of the distribution of PPs has shown a gender and contextual variation. A gender-related variation has been found with a pattern similar to the one illustrated in Hirschmann (1994) and Tannen (1990). Moreover, PPs use varies according to the communicative framework and speakers' pragmatic goals: Using Bravo's (1999) notions, PPs show more autonomía or instead more afiliación towards the addressee or the audience.

In a cross-linguistic perspective, it is interesting to note the similarities in this pragmatic use of PPs between Ancient Greek and other languages. For instance, Hacohen \& Schegloff (2006) demonstrate that Hebrew 1st person singular pronouns tend to occur in conversations where the speaker wants to show disagreement with a previous statement, in a way similar to what happened for Ancient Greek in the fighting framework (e.g. Lys. 430-613). It is also noteworthy how the two leaders Lysistrata and Praxagora use the 1st person singular pronoun (gr. eg⿳亠े⿵冂) to mark their authority among the other women (e.g. Lys. 1-253, Eccl. 1-284) or when they quarrel with men (e.g. Lys. $1112-1188)^{34}$. The claim here is that in these cases 1 st person singular pronouns are pragmatically used by the speaker to hold the centre stage and to mark her authority over her audience.

On the other hand, the use of 1st person plural pronouns (gr. hèmeîs) varies

${ }^{34}$ In our interpretation, these are not instances of non-standard use of the 1st person singular pronoun in the sense indicated by Zobel (2010) for the German ich, whose semantic can sometimes be similar to the impersonal pronoun man. In fact, in our data an impersonal interpretation is not possible, at least in the instances found in the two analysed comedies. 
between the fighting and the chatting frameworks, basically according to the speaker's communicative goals; some instances of referential ambiguity have also been found (e.g., Eccl., line 599). As Pavlidou (2012) points out, a 1st person plural pronoun is always ambivalent throughout a conversation, in the sense that «it does not remain constant, even if uttered by the same speaker, during the same stretch of discourse; on the contrary, it may change and get reconstructed with every utterance, indicating varying alliances and allegiances» (Pavlidou 2012: 34). The use of a 1st person plural pronoun as a marker for negotiating identity and establishing relationships has also been recognized by Stewart (2001) concerning Spanish nosotros ${ }^{35}$ : She notes how this pronoun may be used to mitigate potential FTAs, as was previously remarked by Brown \& Levinson (1987: 202). For instance, when the speaker wants to obtain something from the hearer, he may address him with a plural pronoun, thus giving him a higher status. The authors also emphasize how plurality is used as a marker of respect in many languages: For instance, in Tamil, this pluralisation «pervades the whole pronominal paradigm», and "we" as well as "you (pl)" may serve as the respected forms for "I" and "you (sg.)" respectively (Brown \& Levinson 1987: 200).

In the analysed Ancient Greek data FTAs are always very direct, and involve the explicit use of singular pronouns. When 1st person plural pronouns occur, they are essentially used for their pragmatic value of membership categorization, thus also involving a negotiation of the identities of both the speaker and the addressee. In this respect, Bazzanella (2009) also remarks the value of 1st person plural pronoun as an intensifier in her study on Italian noi "we".

Moreover, the observations on Ancient Greek are similar to what Pavlidou (2012) has noticed for Modern Greek ${ }^{36}$. In her work, in fact, she claims that in a prodrop language like Greek the explicit instance of a 1st person plural pronoun helps to clarify «the composition of the group or collectivity [sic] referred to (clarifying who belongs to it and who doesn't), the speaker's positioning towards what the addressee says or does» (Pavlidou 2012: 61). This is particularly evident in case of disagreement between the speaker and the addressee, in a way similar to what we have seen in the socalled fighting frameworks (e.g. Lys. 430-613). Therefore, it is possible to say that in Ancient Greek, as well as in Modern Greek and in Spanish, the explicit use of a 1st person plural pronoun can be interpreted as a marker for membership categorization, and this categorization is always negotiated between the speaker and the addressee.

In conclusion, it seems possible to claim that Ancient Greek PPs, just like present-day PPs, exhibit different pragmatic values, essentially referring to membership categories speakers want themselves to associate with or disassociate from. This work confirms some important observations provided in recent works on PPs use in different languages. Moreover, the present analysis concentrates on two communicative frameworks, thus emphasising the importance of the context in the interpretation of the pragmatic value of PPs, in particular in those cases involving referential ambiguity. It has also been stressed how speakers' communicative goals affected PPs use, especially in negotiating identity.

Further research on this topic in Ancient Greek (and maybe in Latin) is needed,

\footnotetext{
${ }^{35}$ See also De Cock (2011), who works on Spanish and English data.

${ }^{36}$ Note that Pavlidou (2012) considers only those instances of 1 st person plural pronouns in the Nominative case, whereas in this contribution no case distinction has been provided in order not to further reduce the already small sample.
} 
first of all by enlarging the corpus at disposal, and then by comparing these findings with the contemporary use of PPs in other languages, as it has been briefly proposed in this contribution.

\section{Acknowledgements}

This work is partially inspired by previous research on female language in Ancient Greek comedy, collected in my MA thesis discussed in September 2010 at the University of Eastern Piedmont (Vercelli). The thesis was supervised by prof. Marina Castagneto and prof. Luigi Battezzato: A special thank is due to both for having introduced me to Ancient Greek and to linguistics respectively. I wish also to thank all the colleagues and friends at the University of Pavia and the Free University of Bozen.

\section{References}

Adams, James N. (1984) Female speech in Latin comedy. Antichton 18: 43-77.

Bain, David (1984) Female speech in Menander. Antichton 18: 24-42.

Bazzanella, Carla (2009) Noi come meccanismo di intensità. In Barbara Gili-Fivela, and Carla Bazzanella (eds.), Fenomeni di intensità nell'italiano parlato. Florence: Cesati, pp. 101-114.

Bonifazi, Anna (2004) кعĩvos in Pindar: Between grammar and poetic intention. Classical Philology 99: 283-299.

Bravo, Diana (1999) ¿Imagen positiva vs. imagen negativa? Pragmática socio-cultural y componentes de face. Oralia 2: 22-45.

Brown, Penelope, and Stephen C. Levinson (1987) Politeness. Some universals in language usage. Cambridge: Cambridge University Press.

Bruno, Carla (forthcoming) Dietro la maschera. Funzioni della prima persona nella lingua della tragedia. Proceedings of the International Colloquium on Ancient Greek Linguistics (N.S.), Rome 2015, March $23 r d-27 t h$.

Davidson, Brad (1996) 'Pragmatic weight' and Spanish subject pronouns. The pragmatic and discourse uses of 'tú' and 'yo' in spoken Madrid Spanish. Journal of Pragmatics 16: 543-565.

Dickey, Eleanor (1996) Greek forms of address. From Herodotus to Lucian. Oxford: Clarendon Press.

De Cock, Barbara (2011) Why we can be you: The use of 1st person plural forms with hearer reference in English and Spanish. Journal of Pragmatics 43: 2762-2775.

Hacohen, Gonen-Dori, and Emanuel A. Schegloff (2006) On the preference for minimization in referring to persons: Evidence from Hebrew conversation. Journal of Pragmatics 38: 1305-1312. 
Helmbrecht, Johannes (2003) Politeness distinctions in second person pronouns. In Friedrich Lenz (ed.), Deictic conceptualization of space, time and person. Amsterdam John Benjamins Publishing Company, pp. 185-203.

Helmbrecht, Johannes (2015) A typology of non-prototypical uses of personal pronouns: Synchrony and diachrony. Journal of Pragmatics 88: 176-189.

Hernández-Campoy, Juan Manuel, and Juan Camilo Conde Silvestre (2012) The handbook of historical sociolinguistics. London: Wiley-Blackwell.

Henderson, Jeffrey (1987) Aristophanes. Lysistrata, edited with introduction and commentary. Oxford: Clarendon Paperbacks.

Hirschman, Lynette (1994) Female-male differences in conversational interaction. Language in Society 23.3: 427-442.

Holmes, Janet (1997) Women, language and identity. Journal of Sociolinguistics 1.2: 195-223.

Hughes, Alan (2011) Perfoming Greek comedy. Cambridge: Cambridge University Press.

Hymes, Dell (1974) Foundations in sociolinguistics: An ethnographic approach. London: Tavistock.

MacDowell, Douglas M. (1995) Aristophanes and Athens. An introduction to the plays. Oxford: Oxford University Press.

McClure, Laura K. (1999) Spoken like a woman: Speech and gender in Athenian drama. Princeton: Princeton University Press.

Meluzzi, Chiara (2010) Lisistrata, Prassagora e le altre: Un'analisi sociolinguistica e pragmatica della lingua delle donne in Aristofane. MA, Vercelli: University of Eastern Piedmont, unpublished.

Meluzzi, Chiara (2012) "You" and "me" in Ancient Greek: The case of three "female" comedies. In Wojciech Sowa, and Stefan Schaffner (eds.), Greek and Latin from an Indo-European perspective 3 (GLIEP 3). Proceedings of the conference held at the Comenius University Bratislava, July 8th-10th 2010, Supplement of IJDL, pp. 81-100.

Meluzzi, Chiara (2014) Gli allocutivi nella "Lisistrata": Proposta di analisi pragmatica. In Maria Pia Marchese, and Alberto Nocentini (a cura di). Il lessico nella teoria e nella storia linguistica. Roma: Il Calamo, pp. 235-240.

Mühlhäusler, Peter, and Rom Harré (1990) Pronouns and people: The linguistic construction of social and personal identity. Oxford: Basil Blackwell.

Olson, Douglas (1992) Names and naming in Aristophanic comedy. The Classical Quarterly 42.2: 304319.

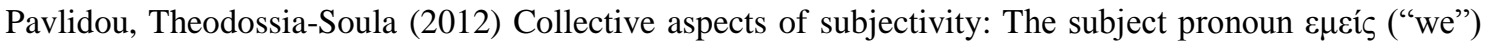
in Modern Greek. In Nicole Baumgarten, Inke Du Bois, and Juliane House (eds.), Subjectivity in language and in discourse. Studies in Pragmatic Sciences 10. London: Brill Academic Pub., pp. 33-65.

Sacks, Harvey, Emanuel A. Schegloff, and Gail Jefferson (1974) A simplest systematics for the organization of turn-taking for conversation. Language 50.4: 696-735.

Schegloff, Emanuel A. (2007) A tutorial on membership categorization, Journal of Pragmatics 39: $462-$ 482 . 
Siewierska, Anna (2004) Person. Cambridge: Cambridge University Press.

Sommerstein, Alan H. (1977) Aristophanes and the events of 411. The Journal of Hellenic Studies 97: $112-126$

Sommerstein, Alan H. (1990) Lysistrata. Warminster: Aris \& Philips.

Sommerstein, Alan H. (1995) The language of Athenian women. In Francesco Di Martino, and Alan H. Sommerstein (eds.), Lo spettacolo delle voci. Bari: Levante, pp. 61-85.

Sommerstein, Alan H. (1998) Ecclesiazusae. Warminster: Aris \& Philips.

Stewart, Miranda (2001) Pronouns of power and solidarity: The case of Spanish first person plural nosotros. Multilingua 20: 155-169.

Stewart, Miranda (2003) 'Pragmatic weight' and face: Pronominal presence and the case of the Spanish second person singular subject pronoun tú. Journal of Pragmatics 35: 191-206.

Tannen, Deborah (1990) You just don't understand. Women and men in conversation. London: Virago Press.

Tannen, Deborah (1994) Talking from 9 to 5. Women and men at work: Language, sex and power. London: Virago Press.

Ussher, Robert G. (2007) Aristophanes Ecclesiazusae. Oxford: Clarendon Press.

Willi, Andreas (2003) The languages of Aristophanes. Aspects of linguistic variation in Classical Attic Greek. Oxford: Oxford University Press.

Wilson, Nigel G. (2007) Aristophanis Fabulae. Oxford: Oxford Classical Texts.

Zobel, Sarah (2010) Non-standard uses of German 1st person singular pronouns. New Frontiers in Artificial Intelligence Lecture Notes in Computer Science 6284: 292-311.

CHIARA MELUZZI is a post-doc researcher at the Scuola Normale Superiore in Pisa (Italy). After her MA in Linguistics on female language in Ancient Greek, she achieved her Ph.D. in Linguistics in 2014 at the University of Pavia and Free University of Bolzano. Her research interests include primarily sociolinguistics and sociophonetics, but also historical linguistics and pragmatics.

Address: via Vercellotto 265, Cossato (B1), Italy. E-mail: chiara.meluzzi@yahoo.it 